\title{
ЗАХОДИ ФІНАНСОВОЇ ВІДПОВІДАЛЬНОСТІ: ПРОБЛЕМАТИКА ПИТАННЯ ПРАВОВОГО МЕХАНІЗМУ ЗУПИНЕННЯ ОПЕРАЦИЙ 3 БЮДЖЕТНИМИ КОШТАМИ
}

Косяченко К. Е.

У науковій статті досліджено сутність механізму зупинення операцій із бюджетними коштами, розкривається певний «каральний» аспект для суб'єкта, яким учинено відповідне правопорушення. Проаналізовано правову природу фінансової відповідальності як складової юридичної відповідальності бюджетного законодавства заходів фінансової відповідальності за порушення останнього. 3 урахуванням вітчизняного досвіду правового механізму зупинення операцій із бюджетними коштами зроблено висновки щодо вдосконалення правового регулювання відповідальності за порушення бюджетного законодавства.

Ключові слова: бюджетні кошти, бюджетне законодавство, асигнування, Державне казначейство, фінансова відповідальність.

В научной статье исследована сущность механизма остановки операций с бюджетными средствами, раскрывается некий «карательный» аспект для субъекта, которым совершено соответствующее правонарушение. Проанализировано правовую природу финансовой ответственности как составляющей юридической ответственности бюджетного законодательства мер финансовой ответственности за нарушение последнего. С учетом отечественного опыта правового механизма остановки операций с бюджетными средствами сделаны выводы по совершенствованию правового регулирования ответственности за нарушение бюджетного законодательства.

Ключевые слова: бюджетные средства, бюджетное законодательство, ассигнования, Государственное казначейство, финансовая ответственность.

The scientific article investigates the nature of the mechanism of suspension of operations with budget funds, reveals a certain "punitive" aspect for the subject who committed the offense. The legal nature of financial responsibility as a component of the legal responsibility of the budget legislation of measures of financial responsibility for violation of the latter is analyzed. Taking into account the domestic experience of the legal mechanism of suspension of operations with budget funds, conclusions were made regarding the improvement of the legal regulation of liability for violations of budget legislation.

Taking into account the domestic experience of the legal mechanism of suspension of operations with budget funds, conclusions were made regarding the improvement of the legal regulation of liability for violations of budget legislation.

An author marks that a certain drawback of the budget legislation is the lack of clear criteria for differentiating the duration of the termination of operations with budget funds. Legal regulation of measures of influence for violation of budget legislation, enshrined in the Budget Code of Ukraine, requires further elaboration and improvement by introducing appropriate amendments to the legal acts that regulate the procedure for application of such measures.

Косяченко К. Е., 2019
Also in addition to the analyzed measures of influence for violation of budget legislation, other measures, for example: the return of budget funds to a specific budget, the suspension of a decision on the local budget, the suspension of operations with budget funds, the suspension of budget allocations, the suspension of budget allocations applicable to these entities if they violate budget legislation, can be applied to budget institutions as expenditure units at different levels.

Key words: budgetary funds, budgetary legislation, appropriations, governmental purpose, appropriate responsibility.

Постановка проблеми та їі актуальність. Визначення правової природи фінансової відповідальності як складової юридичної відповідальності має не лише теоретичне, а й практичне значення. Це пов'язано 3 тим, що фінансова відповідальність $\epsilon$ комплексною категорією й заходи такої відповідальності також $є$ різноманітними за своєю суттю. Так, система заходів, які можуть застосовуватись у разі порушення податкового, бюджетного, валютного чи банківського законодавства, характерні лише для конкретного підгалузевого виду правовідносин і не можуть застосовуватись за вчинення інших правопорушень. Також розглядається питання розкриття правового механізму зупинення операцій з бюджетними коштами.

Аналіз останніх досліджень і публікацій. Теоретичну базу дослідження становлять праці таких науковців, як Ю.С. Назар, Л.Р. Барашян, Д.В. Будніков, 3.М. Будько, Д.О. Гетманцев, О.О. Гогін, Т.О. Гусєва, Є.С. Єфремова, О.В. Зімін, О.В. Золотухін, В.А. Кінсбурська, Н.О. Лабутіна, В.О. Маехін, Ю.В. Рудовер, А.В. Роздайбіда, М.Я. Сакали, А.М. Сердцев, Д.В. Тютін, Д.Ю. Чарухін, Р.С. Юрмашев та інші. Однак проблеми фінансової відповідальності за порушення бюджетного законодавства та особливостей іï правової природи залишаються дискусійними.

Метою статті $\epsilon$ розкриття правового механізму зупинення операцій із бюджетними коштами, відповідальності за порушення фінансового законодавства та внесення пропозицій щодо шляхів удосконалення бюджетного законодавства.

Виклад основного матеріалу. За порушення бюджетного законодавства до бюджетних установ можуть застосовуватися заходи впливу. Наразі чимало науковців намагаються класифікувати такі заходи впливу за різними критеріями, відзначити особливе призначення кожного з них. Так, Д.С. Шутлів вважає, що найбільш змістовною класифікацією $\epsilon$ їх розподіл за функціональним критерієм на такі види:

1) попереджувальні (превентивні);

2) правовідновлюючі;

3) правоприпиняючі;

4) юридичну відповідальність [1, с. 119]. 


\section{Економічна безпека держави: теорія і практика}

Схожими $є$ міркування А.Й. Іванського. Вчений наголошує на існуванні низки заходів попереджувального, припиняючого, карального й відновлювального характеру, які застосовуються до відповідних суб'єктів [2, с. 18]. Якщо розглянути всі заходи впливу за вчинення бюджетних правопорушень, можна констатувати відсутність у їх переліку превентивних заходів, оскільки останні мають попереджувати вчинення порушень, а не застосовуватися вже після їх вчинення та виявлення відповідними суб'єктами. До групи превентивних заходів за порушення бюджетного законодавства доцільно відносити заходи фінансового контролю.

Розкриваючи правовий механізм зупинення операцій із бюджетними коштами, слід позначити важливий момент. Ідеться про певний «каральний» аспект для суб'єкта, яким вчинено відповідне правопорушення. Він якраз і полягає в тому, що у правопорушника немає можливостей провадити операції з бюджетними коштами за конкретною бюджетною програмою. Такі обмеження встановлюються строком до 30 днів. Фактично законодавець закріплює лише верхню межу, граничний строк, на який можливе зупинення операцій із здійснення платежів із рахунку розпорядника чи одержувача бюджетних коштів. Цей строк відраховується із дня надходження рішення про зупинення операцій до Державного казначейства України. Мінімальної тривалості такого заходу не встановлено. При цьому вибір відповідного строку здійснюється на власний розсуд суб'єкта, який уповноважений на застосування такого заходу фінансової відповідальності. Також слід зазначити, що певним недоліком законодавства $\epsilon$ відсутність чітких критеріїв диференціації тривалості зупинення операцій із бюджетними коштами, це питання $\epsilon$ принциповим зважаючи на те, що розглядуваний захід може застосовуватися за низку правопорушень, які відрізняються за своєю суттю та ступенем «шкідливості» для бюджетно-правового регулювання.

Розглянувши правовий механізм застосування зупинення операцій з коштами бюджетів, можна зробити висновок, що критерієм для диференціації строку, на який зупиняються операції відповідного розпорядника чи одержувача бюджетних коштів, може бути характер тих правопорушень, що вчиняються. Відповідно до п. 2 ч. 1 ст. 117 Бюджетного кодексу України зупинення операцій із бюджетними коштами застосовуються за порушення бюджетного законодавства, визначені пунктами 1-3, 10, 11, 14-29, 32-36, 38, 40 ч. 1 ст. 116 цього ж Кодексу [3].

Наведені правопорушення було поділено на кілька груп:

1) пов'язані із включенням недостовірних даних та визначенням неправомірних обсягів бюджетних коштів (пп. 1, 3, 32, 35, 36 ч. 1 ст. 116 Бюджетного кодексу України);

2) пов'язані із порушенням відповідних порядків та строків ( пп. 2, 10, 11, 14-19, 21-23, 25-29, 33, 34, 38 ч. 1 ст. 116 Бюджетного кодексу України);

3) пов'язані з розміщенням та використанням бюджетних коштів не за призначенням (пп. 10, 11, 14, 24, 27 ч. 1 ст. 116 Бюджетного кодексу України).

Вбачаємо неможливим розрізнити строки застосування зупинення операцій із бюджетними коштами. Це пояснюється тим, що будь-яке із цих правопорушень негативно впливає на стан бюджетної системи, якість бюджетного процесу тощо.
У вже згадуваній ч. 2 ст. 120 Бюджетного кодексу України зазначено, що законом може передбачатися й інший граничний строк зупинення операцій із бюджетними коштами. Тож, природно, виникає потреба у визначенні обставин, за яких цей строк може бути скорегований. Схоже міркує й Ю.С. Назар, указуючи, що питання, пов'язані із визначенням різноманітних строків при застосуванні до суб'єкта заходів впливу за порушення бюджетного законодавства, потребують чіткої регламентації [4, с. 127]. Відсутність чіткого визначення строків може стати причиною зловживання правом із боку вповноважених органів на застосування таких заходів.

Зупинені операції з бюджетними коштами обов'язково підлягають відновленню. Згідно з п. 8 Порядку № 21 [5] це відбувається у разі закінчення строку, що (1) зазначений у розпорядженні про зупинення операцій або (2) встановлений ч. 2 ст. 120 Бюджетного кодексу України, шляхом ухвалення рішення про відновлення таких операцій органом, який прийняв рішення про зупинення операцій із бюджетними коштами. При цьому відновлення операцій із бюджетними коштами не позбавляє уповноважені органи права повторного застосування такого заходу впливу за порушення вимог бюджетного законодавства, як зупинення операцій із бюджетними коштами, до тих же розпорядників та/або одержувачів у разі не усунення або вчинення зазначених порушень у подальшому [3, п. 14].

Крім проаналізованих заходів впливу за порушення бюджетного законодавства, до бюджетних установ як розпорядників бюджетних коштів різних рівнів можуть вживатися й інші заходи. Наприклад, призупинення бюджетних асигнувань застосовується до вказаних суб'єктів у разі вчинення ними порушень бюджетного законодавства, визначених у п. 20, 22-29, 38, 40 ч. 1 ст. 116 Бюджетного кодексу України [3, п. 3 ч. 1 ст. 117]. Порядок застосування призупинення бюджетних асигнувань регламентовано наказом Міністерства фінансів України від 15 травня 2002 р. № 319 (далі Порядок № 319 - К. К.) [5]. Призупинення бюджетних асигнувань мають право застосовувати до розпорядників бюджетних коштів такі суб'єкти, як:

- Міністерство фінансів України;

- Державна казначейська служба України;

- Державна аудиторська служба України; Крим;

- Міністерство фінансів Автономної Республіки

- місцеві фінансові органи;

- головні розпорядники бюджетних коштів [5, п. 1].

Указані суб'єкти можуть ініціювати застосування призупинення бюджетних асигнувань до розпорядників бюджетних коштів, однак рішення про застосування вказаного заходу приймає Міністр фінансів України, Міністр фінансів Автономної Республіки Крим, керівник місцевого фінансового органу на підставі протоколу про порушення бюджетного законодавства або акта ревізії та доданих до нього документів [5, абз. 1 п. 3].

Цілком логічним $\epsilon$ твердження Л.К. Воронової про сутність фінансово-правової відповідальності: «це правовідносини, що виникають у галузі фінансової діяльності між державою або органами місцевого самоврядування та іншими суб'єктами фінансових відносин (фізичними особами, юридичними особами) на підставі фінансового правопорушення та в яких реалізуються несприятливі наслідки за порушення фінансово-правових норм» $[6$, с. 494]. 


\section{теорія і практика}

Висновки. Якщо проаналізувати бюджетне законодавство, то можна дійти висновку, що суб'єктом, який вчиняє правопорушення, завжди буде виступати бюджетна установа як розпорядник бюджетних коштів відповідного рівня чи одержувач бюджетних коштів, а уповноваженим на застосування заходів фінансової відповідальності кожного разу виступатиме різний владний суб'єкт (залежно від того, який захід буде застосовуватись). Що стосується несприятливих наслідків для правопорушника, то вони полягатимуть у застосуванні до нього певних обмежень, унаслідок яких він не зможе певною мірою реалізувати заплановане.

Зважаючи на викладене, було б доцільно внести зміни до Порядку № 21 і закріпити абз. 2 п. 6 із таким змістом: «Протягом строку, на який зупинено операції з бюджетними коштами розпоряднику та/або одержувачу бюджетних коштів, відповідне правопорушення має бути усунено. У разі неусунення вчиненого правопорушення до такого розпорядника та/або одержувача бюджетних коштів застосовуються інші заходи впливу за порушення бюджетного законодавства». Сподіваємось, що такі зміни до законодавства сприятимуть оптимізації діяльності вищезазначених суб'єктів у контексті усунення вже вчинених порушень бюджетного законодавства й запобігання їм у подальшому.

\section{Література}

1. Шутлів Д.С. Правовідновлювальні заходи примусу у бюджетно-правовому регулюванні. Науково-інформаційний вісник Івано-Франківського університету права імені Короля Данила Галицького : Журнал. Серія Право. № 2 (14), 2016. С. 119.

2. Іванський А.Й. Фінансово-правова відповідальність в сучасній Україні : теоретичне дослідження : автореф. дис. ... д-ра юрид. наук. Одеса, 2009. С. 18.

3. Бюджетний кодексу України від 08 лип. 2010 p. № 2456VI. URL: http://zakon2.rada.gov.ua/laws/show/2456-17.

4. Назар Ю. С. Щодо строків прийняття рішення про застосування окремих заходів впливу за порушення бюджетного законодавства. Вісник Чернівецького факультету Національного університету «Одеська юридична академія». 2015. № 4 С. 127.

5. Про затвердження Порядку зупинення операцій 3 бюджетними коштами: постанова Кабінету Міністрів України від 19 січ. 2011 р. № 21. URL: http: / /zakon2.rada.gov.ua/ laws/show/21-2011-п.

6. Словник фінансово-правових термінів / за заг. ред. Л. К. Воронової. Київ: Алерта, 2011. С. 494.

Косяченко К. Е., кандидат юридичних наук, доцент кафедри цивільно-правових дисциплін Дніпропетровського державного університету внутрішніх справ 